\title{
Perceptual and Motor Components at Young Football Players
}

\author{
Sinan Bozkurt \\ Correspondence: Sinan Bozkurt, Department of Physical Education and Sports Teaching, Faculty of Sports Science, \\ Marmara University, Istanbul, Turkey. \\ Received: November 21, 2017 \\ Accepted: December 12, 2017 \\ Online Published: December 31, 2017 \\ doi:10.11114/jets.v5i13.2906 \\ URL: https://doi.org/10.11114/jets.v5i13.2906
}

\begin{abstract}
The purpose of this study was to determine some perceptual and motor components level of young football players and to investigate the relationships between perceptual and motor components. Thirty-eight (38) selected football players from different division of Turkey whose mean age was $13.50 \pm .42$ years, height $150.00 \pm 5.60 \mathrm{~cm}$ and body weight $40.00 \pm 4.75 \mathrm{~kg}$ were tested as voluntarily in this study. This study was conducted in the Riva Orhan Saka Facility of the Turkish Football Federation. The findings indicated that statistically significant relations were observed between visual reaction time and anticipation time and also between sit-ups and sprint time, reaction time and agility times. On the other hands, there is no significant relation was found in other parameters.
\end{abstract}

These findings may be useful for trainer and physical education teachers in the selection process and talent identification and preparing sport education programs.

Keywords: football, anticipation time, reaction time, perceptual skills, talent identification, agility, speed, motor skills

\section{Introduction}

In sport performance requires not only physical and motor capabilities but also perceptual-cognitive skills (Williams \& Ericson, 2005). All sports require high perceptual abilities to perform motor skills proficiently (Mori, Ohtani \& Imanaka, 2002). Reaction time and anticipation time are critical aspects of perceptual abilities in sports (Meng et al., 2015).

Reaction time is the elapsed time between the presentation of a sensory stimulus and the subsequent behavioral response. It represents the level of neuromuscular coordination in which the body through different physical, chemical and mechanical processes decodes visual or auditory stimuli which travel via afferent pathways and reach the brain as sensory stimuli (Shelton \& Kumar, 2010).

Anticipation timing is mainly defined as the ability to predict when an object/image would arrive at a designated target point in time and space. Anticipatory skill plays an important role in successful decision-making (Vaeyens, Lenoir, Williams, \& Philippaerts, 2007). Anticipation timing has been used as a perceptual and motor test in assessing the improvements of athletes and also for talent identification (Ripoll \& Latiri, 1997)

The motor skills are gained and developed, such as agility depending on the development of the nervous system (Gallahue, 1982). Soccer is a highly demanding game in which the players are subjected to numerous actions that require such as speed, muscular strength, agility. Speed is the ability to overcome a distance in the shortest time possible. It is affected by reaction time as well as movement time (Spodek \& Saracho, 2006). Agility is a key requirement for optimal performance in many sports and young football player (Singh, Sathe \& Sandhu 2017; Oliver, Lloyd, \& Rumpf, 2013). In fact, it has been reported that speed, agility and dribbling a ball were the best predictors of talented players in soccer and need to be developed from a young age (Reilly, Williams, Nevill, \& Franks, 2000).

As far as we know there are few study on relationship between anticipation time, reaction time an motor parameters at young football players. Therefore, the purpose of this study was to determine some perceptual and motor components level of young football players and to investigate the relationships between perceptual and motor components.

\section{Method}

Thirty-eight (38) selected football players from different division of Turkey whose mean age was $13.50 \pm .42$ years, height $150.00 \pm 5.60 \mathrm{~cm}$ and body weight $40.00 \pm 4.75 \mathrm{~kg}$ were tested as voluntarily in this study. This study was conducted in the Riva Orhan Saka Facility of the Turkish Football Federation. Before measurements, the information was given to players about measurement protocols. 


\subsection{Reaction Time Test}

For the measurement of reaction time, choice reaction times were measured by using the instrument called Lafayette (model 54035A, In USA). The participants were asked to stop the time by pushing to the button with same colour as the visual stimulus when the light stimulus with red, green, white or blue color was applied. The test was repeated five times. Excluding the one fastest and the one slowest values, others' arithmetic reaction time average was calculated and recorded in miliseconds (msec.)

\subsection{Anticipation Time Test}

Each participant was familiarised with the Bassin Anticipation Timer (model 35575, Lafayette, USA) given 5 attempts at each of stimulus speeds used in the test (1,5 and $10 \mathrm{mph}) .15$ attempts' arithmetic average was calculated and recorded in miliseconds (msec.)

None of the lights on the runway were blanked and the target light was light \# 10 of apparatus' second block. The sequentially lighted LED lamps illuminate in a linear pattern with movement occuring from left to right. For each trial, the signal was initiated by the experimenter, with the participant being asked to press a trigger button, with their dominant hand, as close to the arrival time of the stimulus at the target location as possible (Rudisill, 1992; Bozkurt, 2004; Akpınar, Devrilmez \& Kirazc1, 2012).

\subsection{Sit-ups Test}

For sit-ups measurements, the participants were asked to repeat as quick as possible at 30 seconds.

\subsection{Sprint Test}

Distance of 30-meter was selected to evaluate running performance. The participants performed two maximal sprint efforts over the distance of $30 \mathrm{~m}$. on a grass tracks 3-minute interval between trials. Participants begun with their preferred foot placed forward on a line merked on the pitch. Sprint times recorded in miliseconds (msec.) accuracy by photoelectric cells. The best time was used statistical analysis.

\subsection{Agility (with the Ball) Tests}

Agility was defined as the ability to change direction rapidly without loss of speed (Brughelli, Cronin, Levin, Chaouachi, 2008). Start and finish lines were marked by two pairs of photocells $2 \mathrm{~m}$. apart. The test consisted of a maximal slalom sprint of 30 m. (Açıkada, Hazır, Aşçı, Turnagöl \& Özkara, 1998)

\subsection{Statistical Analysis}

Descriptive statistics are presented as arithmetic means, standart deviations, minimum and maximums. The relationships between the perceptual and motor components were tested for significance by using multiple correlations. The level of significance taken into account was $(\mathrm{p}<0.05)$.

\section{Results}

Table 1. Descriptive Statistics for Perceptural and Motor Components

\begin{tabular}{llllll}
\hline Variable & N & Min. & Max. & Mean & St.Dev. \\
\hline Age (years) & 38 & 12.11 & 13.90 & 13.50 & .42 \\
Height (cm) & 38 & 138.00 & 160.00 & 150.00 & 5.60 \\
Body weight (kg) & 38 & 32.00 & 50.00 & 40.00 & 4.75 \\
Visual Choice Reaction (msec) & 38 & 303.33 & 633.00 & 456.07 & 70.41 \\
Anticipation (msec) & 38 & 31.33 & 89.67 & 53.89 & 13.00 \\
30 m.Sprint (sec) & 38 & 4.07 & 5.55 & 4.96 & .25 \\
Agility (sec) & 37 & 9.32 & 12.13 & 10.15 & .60 \\
Agility with the ball (sec) & 37 & 11.86 & 16.63 & 13.64 & 1.12 \\
Sit-ups (rep) & 38 & 14 & 31 & 24.52 & 3.02 \\
\hline
\end{tabular}

Descriptive statistics of the participants were presented in Table 1. Applied tests and mean value of results for the players were La Fayette Instrument Visual Choice Reaction Test 456.07 $\pm 11,42 \mathrm{msec}), 30 \mathrm{~m}$. Sprint Test (4.96 \pm 0.04 $\mathrm{msec})$, Bassin Anticipation Timer Test $(53.89 \pm 2.10 \mathrm{msec})$, Agility Test $(10.15 \pm 0.09 \mathrm{sec})$, Agility Test with the Ball $(13.64 \pm 0.18 \mathrm{sec})$ and $30 \mathrm{sec}$. Sit-ups Test $(24.52 \pm 0.49 \mathrm{rep}$.

Table 2. Correlation test results between visual choice reaction time and anticipation time in the study group

\begin{tabular}{llllll}
\hline Variable & N & Mean & $\begin{array}{l}\text { Standart } \\
\text { deviation }\end{array}$ & $\begin{array}{l}\text { Correlation } \\
(\mathbf{r})\end{array}$ & $\begin{array}{l}\text { Significance } \\
\text { Level (P) }\end{array}$ \\
\hline Visual Choice Reaction & 38 & 456.07 & 70.41 & 0.350 & 0.031 \\
Anticipation & 38 & 53.89 & 13.00 & & $\mathrm{p}<0.05$ \\
\hline
\end{tabular}


Table 3. Correlation test results between visual choice reaction time and $30 \mathrm{~m}$. sprint in the study group

\begin{tabular}{llllll}
\hline Variable & N & Mean & $\begin{array}{l}\text { Standart } \\
\text { deviation }\end{array}$ & $\begin{array}{l}\text { Correlation } \\
(\mathbf{r})\end{array}$ & $\begin{array}{l}\text { Significance } \\
\text { Level (P) }\end{array}$ \\
\hline Visual Choice Reaction & 38 & 456.07 & 70.41 & 0.130 & 0.438 \\
30 m. Sprint & 38 & 4.96 & 0.25 & & $\mathrm{p}>0.05$ \\
\hline
\end{tabular}

Table 4. Correlation test results between visual choice reaction time and agility in the study group

\begin{tabular}{llllll}
\hline Variable & N & Mean & $\begin{array}{l}\text { Standart } \\
\text { deviation }\end{array}$ & $\begin{array}{l}\text { Correlation } \\
(\mathbf{r})\end{array}$ & $\begin{array}{l}\text { Significance } \\
\text { Level (P) }\end{array}$ \\
\hline Visual Choice Reaction & 38 & 456.07 & 70.41 & 0.168 & 0.319 \\
Agility & 37 & 10.15 & 0.60 & & $\mathrm{p}>0.05$ \\
\hline
\end{tabular}

Table 5. Correlation test results between visual choice reaction time and agility with the ball in the study group

\begin{tabular}{llllll}
\hline Variable & N & Mean & $\begin{array}{l}\text { Standart } \\
\text { deviation }\end{array}$ & $\begin{array}{l}\text { Correlation } \\
(\mathbf{r})\end{array}$ & $\begin{array}{l}\text { Significance } \\
\text { Level (P) }\end{array}$ \\
\hline $\begin{array}{l}\text { Visual Choice Reaction } \\
\text { Agility with the ball }\end{array}$ & 38 & 456.07 & 70.41 & 0.068 & 0.303 \\
p & 13.64 & 1.12 & 0.05 \\
\hline
\end{tabular}

Table 6. Correlation test results between anticipation time and $30 \mathrm{~m}$. sprint in the study group

\begin{tabular}{llllll}
\hline Variable & N & Mean & $\begin{array}{l}\text { Standart } \\
\text { deviation }\end{array}$ & $\begin{array}{l}\text { Correlation } \\
(\mathbf{r})\end{array}$ & $\begin{array}{l}\text { Significance } \\
\text { Level (P) }\end{array}$ \\
\hline Anticipation & 38 & 53.89 & 13.00 & -0.025 & 0.883 \\
30 m. Sprint & 38 & 4.96 & 0.25 & & $\mathrm{p}>0.05$ \\
\hline
\end{tabular}

Table 7. Correlation test results between anticipation time and agility in the study group

\begin{tabular}{llllll}
\hline Variable & N & Mean & $\begin{array}{l}\text { Standart } \\
\text { deviation }\end{array}$ & $\begin{array}{l}\text { Correlation } \\
(\mathbf{r})\end{array}$ & $\begin{array}{l}\text { Significance } \\
\text { Level (P) }\end{array}$ \\
\hline Anticipation & 38 & 53.89 & 13.00 & 0.180 & 0.285 \\
Agility & 37 & 10.15 & 0.60 & & $\mathrm{p}>0.05$ \\
\hline
\end{tabular}

Table 8. Correlation test results between anticipation time and agility with the ball in the study group

\begin{tabular}{llllll}
\hline Variable & N & Mean & $\begin{array}{l}\text { Standart } \\
\text { deviation }\end{array}$ & $\begin{array}{l}\text { Correlation } \\
(\mathbf{r})\end{array}$ & $\begin{array}{l}\text { Significance } \\
\text { Level (P) }\end{array}$ \\
\hline Anticipation & 38 & 53.89 & 13.00 & 0.134 & 0.430 \\
Agility with the ball & 37 & 13.64 & 1.12 & & $\mathrm{p}>0.05$ \\
\hline
\end{tabular}

Table 9. Correlation test results between anticipation time and sit-ups in the study group

\begin{tabular}{llllll}
\hline Variable & N & Mean & $\begin{array}{l}\text { Standart } \\
\text { deviation }\end{array}$ & $\begin{array}{l}\text { Correlation } \\
(\mathbf{r})\end{array}$ & $\begin{array}{l}\text { Significance } \\
\text { Level (P) }\end{array}$ \\
\hline Anticipation & 38 & 53.89 & 13.00 & -0.032 & 0.847 \\
Sit - ups & 38 & 24.52 & 3.02 & & $\mathrm{p}>0.05$ \\
\hline
\end{tabular}

Table 10. Correlation test results between agility with the ball and $30 \mathrm{~m}$. sprint in the study group

\begin{tabular}{llllll}
\hline Variable & N & Mean & $\begin{array}{l}\text { Standart } \\
\text { deviation }\end{array}$ & $\begin{array}{l}\text { Correlation } \\
(\mathbf{r})\end{array}$ & $\begin{array}{l}\text { Significance } \\
\text { Level (P) }\end{array}$ \\
\hline $\begin{array}{l}\text { Agility with the ball } \\
\text { 30 m. Sprint }\end{array}$ & 37 & 13.64 & 1.12 & 0.122 & 0.472 \\
p $>0.05$
\end{tabular}

Table 11. Correlation test results between agility with the ball and agility in the study group

\begin{tabular}{llllll}
\hline Variable & N & Mean & $\begin{array}{l}\text { Standart } \\
\text { deviation }\end{array}$ & $\begin{array}{l}\text { Correlation } \\
(\mathbf{r})\end{array}$ & $\begin{array}{l}\text { Significance } \\
\text { Level (P) }\end{array}$ \\
\hline Agility with the ball & 37 & 13.64 & 1.12 & 0.399 & 0.015 \\
Agility & 37 & 10.15 & 0.60 & & $\mathrm{p}<0.05$ \\
\hline
\end{tabular}

Table 12. Correlation test results between sit-ups and $30 \mathrm{~m}$. Sprint in the study group

\begin{tabular}{llllll}
\hline Variable & N & Mean & $\begin{array}{l}\text { Standart } \\
\text { deviation }\end{array}$ & $\begin{array}{l}\text { Correlation } \\
(\mathbf{r})\end{array}$ & $\begin{array}{l}\text { Significance } \\
\text { Level }(\mathbf{P})\end{array}$ \\
\hline Sit - ups & 38 & 24.52 & 3.02 & -0.484 & 0.002 \\
30 m. Sprint & 38 & 4.96 & 0.25 & 0.01 \\
\hline
\end{tabular}

Table 13. Correlation test results between sit-ups and agility in the study group

\begin{tabular}{lcclll}
\hline Variable & N & Mean & $\begin{array}{l}\text { Standart } \\
\text { deviation }\end{array}$ & $\begin{array}{l}\text { Correlation } \\
(\mathbf{r})\end{array}$ & $\begin{array}{l}\text { Significance } \\
\text { Level }(\mathbf{P})\end{array}$ \\
\hline Sit - ups & 38 & 24.52 & 3.02 & -0.343 & 0.038 \\
Agility & 37 & 10.15 & 0.60 & & $\mathrm{p}<0.01$ \\
\hline
\end{tabular}


Table 14. Correlation test results between sit-ups and agility with the ball in the study group

\begin{tabular}{llllll}
\hline Variable & N & Mean & $\begin{array}{l}\text { Standart } \\
\text { deviation }\end{array}$ & $\begin{array}{l}\text { Correlation } \\
(\mathbf{r})\end{array}$ & $\begin{array}{l}\text { Significance } \\
\text { Level (P) }\end{array}$ \\
\hline Sit - ups & 38 & 24.52 & 3.02 & -0.350 & 0.034 \\
Agility with the ball & 37 & 13.64 & 1.12 & & $\mathrm{p}<0.01$ \\
\hline
\end{tabular}

Table 15. Correlation test results between sit-ups and Visual Choice Reaction in the study group

\begin{tabular}{llllll}
\hline Variable & N & Mean & $\begin{array}{l}\text { Standart } \\
\text { deviation }\end{array}$ & $\begin{array}{l}\text { Correlation } \\
(\mathbf{r})\end{array}$ & $\begin{array}{l}\text { Significance } \\
\text { Level (P) }\end{array}$ \\
\hline Sit - ups & 38 & 24.52 & 3.02 & -0.366 & 0.024 \\
Visual Choice Reaction & 38 & 456.07 & 70.41 & $\mathrm{p}<0.01$ \\
\hline
\end{tabular}

The correlations between the perceptual and motor components were shown in between Table 2 . with Table 15 . The was a significant correlation between anticipation time and visual choice reaction time scores $(p=0.031 ; \mathrm{r}=-0.350)$ Sit-ups scores correlated with sprint scores $(\mathrm{p}=0.002 ; r=-0.484)$, agility scores $(p=0.038 ; \mathrm{r}=-0.343)$, agility with the ball scores $(p=0.034 ; \mathrm{r}=-0.350)$, visual choice reaction time scores $(p=0.024 ; r=-0.366)$. The was a significant correlation between agility and agility with the ball time scores $(p=0.015 ; r=-0.399)$

There were not statistically significant difference between other parameters $(p>0.05)$.

\section{Discussion}

It is observed that while there are sports studies in which perceptual components and motor components such as speed, agility, strength are addressed in the literature, there are limited number of studies examining the relationship between perceptual componenets such as reaction and anticipation times and motor components.

In this study, in which we tried to o determine some perceptual and motor components level of young football players and to investigate the relationships between perceptual and motor components.

In our study, a significant relationship was found between anticipation time and visual reaction time $(\mathrm{p}<0.05)$. Bozkurt, Erkut \& Akkoç (2017) found a significant relationship between anticipation time and reaction time in the study conducted with school students at the average age of 11.06 years $(\mathrm{p}<0.05)$. These perceptual motor skills affect each other as seen above. The result of this study is parallel with our study.

Strength, speed and agility are abilities that make an important contribution to efficient movement with and without the ball (Fortomme, Croisier, Ciccarone, Crielaard \& Cloes, 2005). It is also possible to conclude that the core strength training may contribute to the speed performance. According to our results of statistically, significant relations were observed between sit-ups and sprint time, agility and agility with the ball, and reaction time, also between agility and agility with the ball $(\mathrm{p}<0.05)$.

We found that there was no significant relation between sprint time and agility in our study $(\mathrm{p}<0.05)$. In a study by Šimonek, Horička and Hianik (2017) although negative relationship was observed between speed and agility performances in football players Little and Williams (2005) study who found a weak correlation between speed and agility in male soccer players. This result is similar to our study.

On the other hands, there is no significant relation was found in other parameters.

These findings may be useful for trainer and physical education teachers in the selection process and talent identification and preparing sport education programs.

\section{Acknowledgements}

The author thanks Football Development Department of Turkish Football Federation and Nuri Topsakal for their assistance in this study.

Note: This study was presented as poster announcement at the 1st Scientific Conference on Motor Skill Acquisition. Kisakallio, Finland, on November 2015.

\section{References}

Açıkada, C., Hazır, T., Aşçı, A., Turnagöl, H., \&Özkara, A. (1998). Bir İkinci Lig Takımının Sezon Öncesi Hazırlık Döneminde Fiziksel ve Fizyolojik Profili. Hacettepe Journal of Sport Science, 1(9), 3-14.

Akpınar, S., Devrilmez, E., \& Kirazc1, S. (2012). Coincidence-Anticipation Timing Requirements are Different in Racket Sports. Perceptual \& Motor Skills: Exercise \& Sport, 115(2), 581-593.

Bozkurt, S. (2004). The Study of Relationship between Creativity and Multiple Intelligence and Creativity in the Sports of Soccer (Unpublished doctoral dissertation).Marmara University Institute of Medical Sciences, Turkey. 
Bozkurt, S., Erkut, O., \& Akkoç, O. (2017). Relationships between Static and Dynamic Balance and Anticipation Time, Reaction Time in School Children at the Age of 10-12 Years. Universal Journal of Educational Research, 5(6), 927-931. https://doi.org/10.13189/ujer.2017.050603

Brughelli, M., Cronin, J., Levin, G., \& Chaouachi, A. (2008). Understanding change of direction ability in sport: a review of resistance training studies. Sports Med., 38, 1045-1063.

https://doi.org/10.2165/00007256-200838120-00007

Forthomme, B., Croisier, J. L., Ciccarone, G., Crielaard, J. M., \& Cloes, M. (2005). Factors correlated with volleyball spike velocity. Am. J. Sports Med., 33, 1513-1519. https://doi.org/10.1177/0363546505274935

Gallahue, D. L. (1982). Understanding Motor Development in Children. Boston. MA: John Wiley \& Sons, Inc.

Little, T., \& Williams, A. G. (2017). Specificity of acceleration, maximum speed, and agility in professional soccer players. Journal of Strength \& Conditioning Research

Meng, Y. K., Zuhairi, A. N., Manan, A. F., Knight, F. V., Padri, A. N. M., \& Omar, R. (2015). Role of Gender, Age and Ethnicities on Visual Reaction Time and Visual Anticipation Time of Junior Athletes. Australian Journal on Basic and Applied Sciences, 9(5), 129-134.

Mori, S., Ohtani, Y., \& Imanaka, K. (2002). Reaction times and anticipatory skills of karate athletes. Human Movement Science, 21, 213-230. https://doi.org/10.1016/S0167-9457(02)00103-3

Oliver, J. L., Lloyd, R. S., \& Rumpf, M. C. (2013). Developing speed through out childhood and adolescent: the role of growth, maturation and training. Strength Cond. J., 35(3), 42-48. https://doi.org/10.1519/SSC.0b013e3182919d32

Reilly, T., Williams, M. A, Nevill, A., \& Franks, A. (2000). A multidisciplinary approach to talent identification in soccer. J. Sports Sci., 18, 695-702. https://doi.org/10.1080/02640410050120078

Ripoll, H., \& Latır1, I. (1997). Effect of expertise on coincident-timing accuracy in a fast ball game. Journal of Sports Sciences, 15, 573-580. https://doi.org/10.1080/026404197367001

Rudisill, E. M. (1992). Theory \& Application of Motor Learning. Lab Manuel, Mac J-R Publishing Company, Texas.

Shelton, J., \& Kumar, P. G. (2010). Comparison between Auditory and Visual Simple Reaction Times. Neuroscience \& Medicine, 1, 30-32. https://doi.org/10.4236/nm.2010.11004

Šimonek, J., Horička, P., \& Hianik, J. (2017). The differences in acceleration, maximal speed and agility between soccer, basketball, volleyball and handball players. Journal of Human Sport and Exercise, 12(1), 73-82. https://doi.org/10.14198/jhse.2017.121.06

Singh, A., Sathe, A., \& Sandhu, J. S. (2017). Effect of a 6-week agility training program on performance indices of Indian taekwondo players. Saudi. J. Sports Med., 17, 139-143. https://doi.org/10.4103/sjsm.sjsm_19_17

Spodek, B., \& Saracho, O. (2006). The handbook of research on the education of young children. 2nd edition. Routledge.

Vaeyens, R. L., Matthieu, A., Mark Williams, M. A., \& Philippaerts, M. R. (2007). Mechanisms Underpinning Successful Decision Making in Skilled Youth Soccer Players: An Analysis of Visual Search Behaviors, Journal of Motor Behavior, 39(5). https://doi.org/10.3200/JMBR.39.5.395-408

Williams, A. M., \& Ericsson, K. A. (2005). Perceptual-cognitive expertise in sport: Some considerations when applying the expert performance approach. Human Movement Science, 24, 283-307.

https://doi.org/10.1016/j.humov.2005.06.002

\section{Copyrights}

Copyright for this article is retained by the author(s), with first publication rights granted to the journal.

This is an open-access article distributed under the terms and conditions of the Creative Commons Attribution license which permits unrestricted use, distribution, and reproduction in any medium, provided the original work is properly cited. 